\title{
Streptococcus equi subsp. ruminatorum subsp. nov., isolated from mastitis in small ruminants
}

Correspondence

José F. Fernández-Garayzábal garayzab@vet.ucm.es

\author{
Elena Fernández, ${ }^{1}$ Verena Blume, ${ }^{1}$ Patricia Garrido, ${ }^{1}$ Matthew D. Collins, ${ }^{2}$ \\ Ana Mateos, ${ }^{1}$ Lucas Domínguez ${ }^{1}$ and José F. Fernández-Garayzábal ${ }^{1}$ \\ 'Departamento de Sanidad Animal, Facultad de Veterinaria, Universidad Complutense, Avenida \\ Puerta de Hierro s/n, Madrid 28040, Spain \\ ${ }^{2}$ School of Food Biosciences, University of Reading, Whiteknights, Reading RG6 6AP, UK
}

\begin{abstract}
Six isolates of an unknown Gram-positive, catalase-negative, chain-forming, coccus-shaped organism isolated from ovine and caprine mastitis were characterized by phenotypic and molecular taxonomic methods. On the basis of cellular morphology and the results of biochemical tests, the organism was tentatively identified as a streptococcal species. Comparative 16S rRNA gene sequencing studies confirmed that the organism is a member of the genus Streptococcus, with Streptococcus equi as its closest phylogenetic relative (98.8\% similarity). DNA-DNA pairing studies showed that the unidentified organism displayed more than $70 \%$ relatedness to the type strains of $S$. equi subsp. equi and subsp. zooepidemicus. Despite the relatively high DNA-DNA reassociation values, biotyping and ribotyping allowed clear differentiation of the unknown bacterium from the two recognized subspecies of $S$. equi. On the basis of phenotypic and molecular genetic evidence, it is proposed that the unknown Streptococcus isolates from ovine and caprine mastitis be classified as a novel subspecies, Streptococcus equi subsp. ruminatorum subsp. nov. The type strain is CECT $5772^{\top}\left(=\right.$ CCUG $\left.47520^{\top}=\mathrm{Mt} 167^{\top}\right)$.
\end{abstract}

Mastitis is one of the most serious economic and health problems of small ruminant flocks worldwide (Las Heras et al., 1999). Streptococci, together with staphylococci, are the most prevalent micro-organisms responsible for mastitis in small ruminants (Menzies \& Ramanoon, 2001). The main species of streptococci causing mastitis are Streptococcus agalactiae, Streptococcus dysgalactiae and Streptococcus uberis (Quinn et al., 1999), although unusual cases of mastitis caused by other species of streptococci such as Streptococcus equi subsp. zooepidemicus or Streptococcus parasanguinis have also been described (Fernández-Garayzábal et al., 1998a; Las Heras et al., 2002). The taxonomy of the genus Streptococcus has improved greatly in recent years as a result of the use of molecular chemical and genetic methods. In particular, the increased use of comparative 16S rRNA gene sequencing has clarified the identification of many taxonomically problematic or aberrant strains and has played a central role in the recognition of many novel streptococcal

Published online ahead of print on 28 June 2004 as DOI 10.1099/ ijs.0.63145-0.

\footnotetext{
Abbreviation: CAMP, Christie-Atkins-Munch-Petersen.
}

The GenBank/EMBL/DDBJ accession number for the 16S rRNA gene sequence of Streptococcus equi subsp. ruminatorum subsp. nov. strain CECT $5772^{\top}$ is AJ605748.

A full version of the dendrogram in Fig. 1, including a wider sample of Streptococcus species, is available as supplementary material in IJSEM Online. species, especially those from animals (Skaar et al., 1994; Devriese et al., 1997, 1999; Rurangirwa et al., 2000; Collins et al., 2002; Vela et al., 2002). During the course of a study of bacteria associated with mastitis in small ruminants, we have isolated, from different animals, six strains of Grampositive, catalase-negative, chain-forming cocci of uncertain taxonomic position. In this article, we report the results of phenotypic and molecular genetic studies of the taxonomy of these Streptococcus-like organisms. On the basis of the findings presented, we describe a novel subspecies of $S$. equi, Streptococcus equi subsp. ruminatorum subsp. nov.

During a routine bacteriological survey to determine the aetiological agents of mastitis in small ruminants, six unidentified isolates were recovered from mastitic milk samples. Four strains (Mt 165, Mt 166, Mt $167^{\mathrm{T}}$ and Mt 168) were isolated from four different sheep with subclinical mastitis, whereas two other strains (Mt 159 and Mt 160) were recovered from goats with clinical mastitis. The latter two goats exhibited acute inflammation of the udder, with the mammary glands being hard, swollen and warm and painful to the touch. The milk secretion had a watery appearance and contained small flocks of pus. The affected sheep did not show either clinical signs of mastitis or milk abnormalities but gave positive results in the California Mastitis Test (score of 2+). This test estimates the degree of inflammation of the mammary gland by detecting increased numbers of leukocytes in the milk. Mammary glands with 
no clinical abnormalities, apparently normal milk secretion, positive in the California Mastitis Test and bacteriologically positive are routinely considered to have subclinical mastitis (Stefanakis et al., 1995; Las Heras et al., 1999). Milk samples $(10 \mathrm{ml})$ were taken aseptically as described previously (Las Heras et al., 1999), then kept at $4{ }^{\circ} \mathrm{C}$ during transportation to the laboratory for microbiological analysis. Milk samples were cultured on Columbia blood agar (bioMérieux) and incubated under aerobic conditions at $37^{\circ} \mathrm{C}$ for $24 \mathrm{~h}$. All of the isolates were recovered in pure culture. In samples from animals with subclinical mastitis, counts of Streptococcuslike organisms were higher than $1 \times 10^{4}$ c.f.u. $\mathrm{ml}^{-1}$. The isolates were characterized biochemically by using the API Rapid ID 32 Strep system according to the manufacturer's instructions (bioMérieux). Acid production from ribose, maltose, mannitol, sorbitol, trehalose, raffinose, sucrose, arabinose, melibiose and melezitose was also tested by using phenol red broth base (Difco) supplemented with $1 \%(\mathrm{w} / \mathrm{v})$ sugar, after incubation for 24 and $48 \mathrm{~h}$ at $37^{\circ} \mathrm{C}$. Conventional physiological tests such as those for acetoin, hydrolysis of urea, hippurate, aesculin or arginine, and the CAMP (Christie-Atkins-Munch-Petersen) test with Staphylococcus aureus CECT 4013 were also determined using conventional procedures (Facklam \& Elliot, 1995). The Lancefield serological group reaction was determined with the commercial Slidex Streptokit (bioMérieux) according to the manufacturer's instructions. The haemolytic reaction was determined on Columbia blood agar plates incubated aerobically at $37^{\circ} \mathrm{C}$ for $24 \mathrm{~h}$. A representative strain $\left(\mathrm{Mt} 167^{\mathrm{T}}\right)$ has been deposited in the Spanish Type Culture Collection (University of Valencia, Spain) and in the Culture Collection of the University of Göteborg (Göteborg, Sweden) under accession numbers CECT $5772^{\mathrm{T}}$ and CCUG $47520^{\mathrm{T}}$, respectively. Comparative $16 \mathrm{~S}$ rRNA gene sequence analyses were performed as described previously (Vela et al., 2002). The closest known relatives of the unknown isolates were determined by performing database searches of the GenBank and Ribosomal Database Project libraries. A phylogenetic tree was constructed according to the neighbour-joining method with the program NEIGHBOR (Felsenstein, 1989). The stability of the groupings was estimated by bootstrap analysis (500 replications) using the programs DNABOOT, DNADIST, NEIGHBOR and CONSENSE (Felsenstein, 1989). DNA-DNA reassociation experiments were carried out according to the spectrophotometric method of De Ley et al. (1970), with the modification described by Escara \& Hutton (1980) and Huß et al. (1983), using a Gilford System model 2600 spectrophotometer equipped with a Gilford model 2527-R thermal programmer. Renaturation rates were computed with the program TRANSFER.BAS (Jahnke, 1992). Automated ribotyping of the isolates using EcoRI was performed using the RiboPrinter system (DuPont Qualicon), as described by Bruce (1996).

All of the Streptococcus-like strains grew on Columbia blood agar at $37^{\circ} \mathrm{C}$ under aerobic conditions, forming $\beta$-haemolytic, non-pigmented, mucoid colonies. The six isolates consisted of Gram-positive, coccus-shaped cells that formed short chains. The unidentified organisms were catalase-negative, facultatively anaerobic, displayed a positive CAMP reaction with $S$. aureus, and gave a positive reaction with Lancefield group $\mathrm{C}$ antiserum. The isolates did not grow at $\mathrm{pH} 9.6$ at $37^{\circ} \mathrm{C}$, in $6.5 \%(\mathrm{w} / \mathrm{v}) \mathrm{NaCl}$ broth or at 10 or $45^{\circ} \mathrm{C}$. They were bile/aesculin-negative. In tests with the commercial API system, all strains produced acid from ribose, cyclodextrin (Mt 159 and Mt 166 gave a weak reaction), pullulan and maltose, but failed to produce acid from mannitol, trehalose, raffinose, sucrose, tagatose, L-arabinose, D-arabitol, melibiose, melezitose or methyl $\beta$-D-glucopyranoside. Five strains produced acid from glycogen (Mt 160, Mt 165, Mt 166, Mt $167^{\mathrm{T}}$ and Mt 168). Four isolates failed to produce acid from sorbitol with the API Rapid ID 32 Strep strips, but the six isolates produced acid from this sugar when using phenol red broth base as described above. Five strains produced acid from lactose (Mt 159, Mt 160, Mt 166, Mt $167^{\mathrm{T}}$ and Mt 168); strain Mt $167^{\mathrm{T}}$ was negative with the API Rapid ID 32 Strep strips but positive when phenol red broth base was used. The higher sensitivity of phenol red broth base in detecting the acidification of some sugars has been observed previously (Fernández-Garayzábal et al., 1998b). All of the strains showed activity for arginine dihydrolase, $\beta$-glucuronidase, alkaline phosphatase and alanine-phenylalanine-proline arylamidase, but activities for $\beta$-glucosidase, $\alpha$-galactosidase, $\beta$-galactosidase, pyroglutamic acid arylamidase, $N$-acetyl- $\beta$-glucosaminidase, glycyl-tryptophan arylamidase and $\beta$-mannosidase were not detected. None of the isolates produced acetoin. They hydrolysed hippurate but not urea or aesculin. The phenotypic characteristics of the isolates were consistent with their assignment to the genus Streptococcus, but they did not appear to correspond to the characteristics of any described species of the genus. In studies with the commercial Rapid ID 32 Strep system, the isolates were identified as doubtful members of Streptococcus group L.

To establish the phylogenetic position of the unknown isolates, their $16 \mathrm{~S}$ rRNA gene sequences were determined by direct sequencing of in vitro-amplified rRNA gene products. For strain CECT $5772^{\mathrm{T}}$, the almost-complete sequence was determined (>1400 nt), whereas approximately $1000 \mathrm{nt}$ were determined for each of the other isolates. Comparative analysis revealed $99 \cdot 8-100 \% 16 \mathrm{~S}$ rRNA gene sequence similarity among the strains, thereby demonstrating high genealogical homogeneity. Sequence searches of the GenBank and Ribosomal Database Project libraries revealed that the unknown isolates were phylogenetically most closely related to the genus Streptococcus (data not shown). Clustering analysis confirmed this affinity, and a dendrogram depicting the phylogenetic relationships of the unidentified coccus (as exemplified by strain Mt $167^{\mathrm{T}}$ ) within the genus Streptococcus is shown in Fig. 1. The unknown bacterium formed a distinct subline associated with S. equi ( $98.8 \%$ similarity) as the closest phylogenetic relative. To investigate the genetic relationships between the 


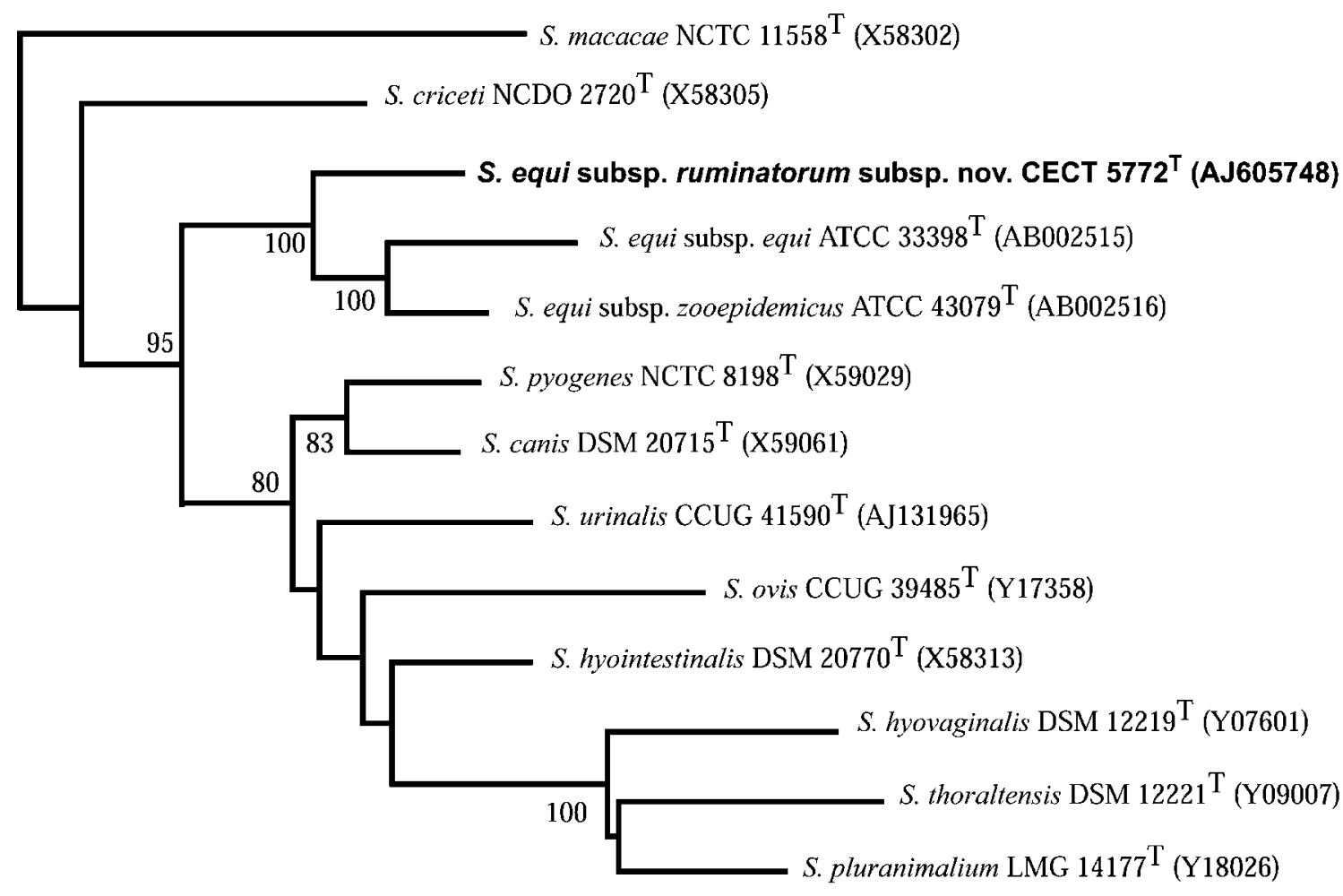

Fig. 1. Neighbour-joining dendrogram, based on 16S rRNA gene sequences, showing the position of the unknown bacterium (as exemplified by strain $\mathrm{Mt} 167^{\top}=\mathrm{CECT} 5772^{\top}$ ) in relation to its nearest phylogenetic relatives. Bootstrap values (each expressed as a percentage of 500 replications) are given at the branching points. Bar, $1 \%$ sequence divergence. A full version of the dendrogram, including a wider sample of Streptococcus species, is available as supplementary material in IJSEM Online.

milk isolates in more detail, chromosomal DNA-DNA hybridizations were performed with a representative strain of each numerical profile (strains Mt 159 and Mt $167^{\mathrm{T}}$ ) and the two subspecies of $S$. equi. The two isolates displayed $100 \%$ DNA relatedness to each other, demonstrating that they are members of the same species. Reassociation values for the unknown bacterium with respect to $S$. equi subsp. equi (DSM 20561 ${ }^{\mathrm{T}}$ ) and with respect to $S$. equi subsp. zooepidemicus (DSM $20727^{\mathrm{T}}$ ) were $82 \cdot 4$ and $70 \cdot 6 \%$, respectively, while the reassociation value between strains DSM $20561^{\mathrm{T}}$ and DSM $20727^{\mathrm{T}}$ was $81 \cdot 4 \%$. These results show that the organism from milk should be assigned to the species S. equi (Wayne et al., 1987). The determination of rRNA gene restriction patterns is a powerful method for investigating the relationships between closely related species and also for distinguishing bacterial subspecies (Doit et al., 1994; Rudney \& Larson, 1994). In ribotyping analyses, the milk isolates displayed distinct rRNA gene restriction patterns with respect to those of the type strains of $S$. equi subsp. equi and S. equi subsp. zooepidemicus, the latter of which exhibited nearly identical ribotypes. Both reference strains of $S$. equi displayed a common band $(4 \cdot 5 \mathrm{kbp})$ and a subset of bands in the range approximately $6-15 \mathrm{kbp}$. The clinical isolates Mt 159 and $\mathrm{Mt} 167^{\mathrm{T}}$ displayed the common band of $4 \cdot 5 \mathrm{kbp}$ but only some of the bands of the $6-15 \mathrm{kbp}$ subset (Fig. 2).

Molecular genetic differences between the milk isolates and the two recognized S. equi subspecies are strongly supported by phenotypic criteria. The two established subspecies (equi and zooepidemicus) can be distinguished from each other by their biochemical reactions, in particular by the failure of subsp. equi to ferment sorbitol. The coccus from mastitic milk samples resembles both subspecies in being $\beta$ haemolytic and possessing the Lancefield group $\mathrm{C}$ antigen, but it does not correspond to either subspecies in terms of its biochemical reactions. Unlike subspp. equi and zooepidemicus, the milk coccus gives a positive CAMP reaction with $S$. aureus, a relatively unusual trait amongst the $\beta$-haemolytic streptococci (being found only in $S$. agalactiae, Streptococcus porcinus, Streptococcus iniae and Streptococcus canis). Furthermore, it differs from both subspecies in hydrolysing hippurate and by fermenting ribose but failing to acidify sucrose and methyl $\beta$-Dglucopyranoside. In addition, unlike subsp. zooepidemicus, the milk coccus fails to ferment sorbitol. Hence, phenotypic criteria facilitate the clear delineation of the unknown milk coccus within a population distinct from subspp. equi and zooepidemicus. Therefore, on the basis of phenotypic 


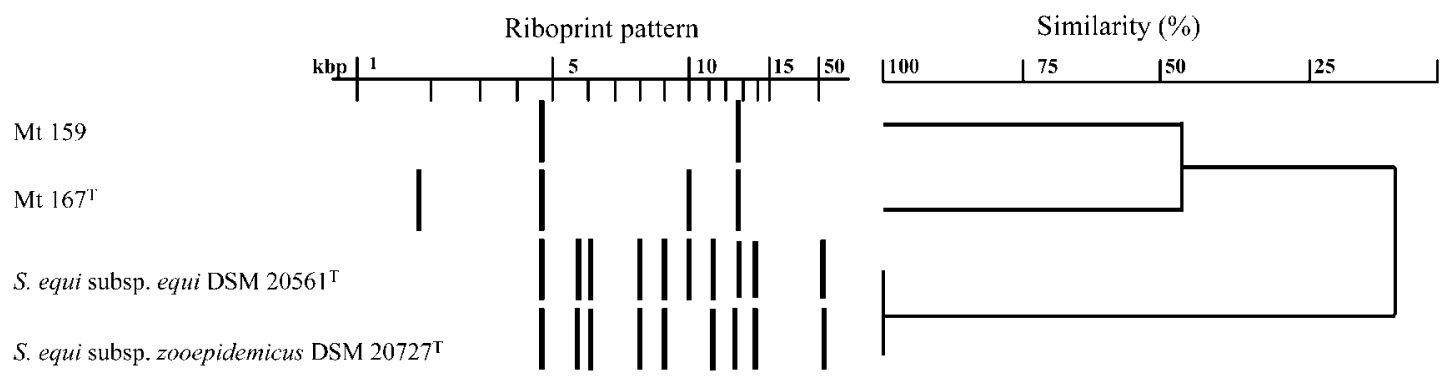

Fig. 2. Dendrogram showing the relatedness of EcoRl riboprint patterns of the milk isolates and the type strains of $S$. equi subsp. equi DSM $20561^{\top}$ and S. equi subsp. zooepidemicus DSM $20727^{\top}$.

evidence and the results of $16 \mathrm{~S}$ rRNA gene sequence analysis, DNA-DNA hybridization assays and ribotyping, we consider that the milk isolates merit separate subspecies status within S. equi, for which the name Streptococcus equi subsp. ruminatorum subsp. nov. is proposed. Tests that are useful in differentiating S. equi subsp. ruminatorum subsp. nov. from other $\beta$-haemolytic streptococci and/or streptococci responsible for mastitis in small ruminants are listed in Table 1.
S. equi subsp. equi causes 'strangles' in horses and, to date, has not been isolated from humans; S. equi subsp. zooepidemicus, on the other hand, is found in animal and human infections (Facklam, 2002; Las Heras et al., 2002). S. equi subsp. ruminatorum subsp. nov. was isolated in pure culture from milk samples from goats and sheep with clinical or subclinical mastitis, respectively. In addition, quantitative detection of $S$. equi subsp. ruminatorum subsp. nov. in milk samples from animals with subclinical mastitis

Table 1. Characteristics useful in distinguishing $S$. equi subsp. ruminatorum subsp. nov. from other $\beta$-haemolytic streptococci and other streptococci responsible for mastitis

Taxa are identified as follows: 1, Streptococcus equi subsp. ruminatorum subsp. nov.; 2, S. equi subsp. equi; 3, S. equi subsp. zooepidemicus; 4, S. pyogenes; 5, S. agalactiae; 6, S. dysgalactiae subsp. dysgalactiae; 7, S. dysgalactiae subsp. equisimilis; 8, S. canis; 9, S. anginosus; 10, S. constellatus subsp. pharyngis; 11, S. porcinus; 12, S. iniae; 13, S. phocae; 14, S. didelphis; 15, S. uberis; 16, S. parasanguinis. Data for species other than S. constellatus subsp. pharyngis (Whiley et al., 1999), S. iniae (Pier \& Madin, 1976; Bromage et al., 1999), S. phocae (Skaar et al., 1994) and S. didelphis (Rurangirwa et al., 2000) were obtained from the Rapid ID 32 Strep database (bioMérieux) and from Kilian (1998) and Facklam (2002). +, Positive; -, negative; V, variable; ND, no data available.

\begin{tabular}{|c|c|c|c|c|c|c|c|c|c|c|c|c|c|c|c|c|}
\hline Test & 1 & 2 & 3 & 4 & 5 & 6 & 7 & $8^{*}$ & 9 & 10 & 11 & 12 & $13 \dagger$ & 14 & 15 & 16 \\
\hline Lancefield group & $\mathrm{C}$ & $\mathrm{C}$ & $\mathrm{C}$ & A & B & $\mathrm{C}$ & $\begin{array}{l}\text { A, C, } \\
\text { G, L }\end{array}$ & G & $\begin{array}{l}\text { A, C, G, } \\
\text { F, none }\end{array}$ & $\mathrm{C}$ & $\begin{array}{l}\mathrm{E}, \mathrm{P}, \mathrm{U}, \\
\mathrm{V}, \text { none }\end{array}$ & None & $\begin{array}{l}\text { C, F, } \\
\text { none }\end{array}$ & None & $\begin{array}{c}\mathrm{E}, \\
\text { none }\end{array}$ & None \\
\hline CAMP reaction & + & - & - & - & + & - & - & + & - & - & + & + & - & - & - & - \\
\hline \multicolumn{17}{|l|}{ Hydrolysis of: } \\
\hline Hippurate & + & - & - & + & + & - & - & - & - & - & - & - & - & - & + & - \\
\hline Aesculin & - & $\mathrm{V}$ & $\mathrm{V}$ & $\mathrm{V}$ & - & $\mathrm{V}$ & + & + & + & + & + & + & - & - & + & $\mathrm{V}$ \\
\hline \multicolumn{17}{|l|}{ Production of: } \\
\hline$\beta$-Mannosidase & - & $\mathrm{V}$ & - & - & - & - & - & - & - & ND & - & ND & ND & ND & - & - \\
\hline Pyrrolidonyl arylamidase & - & - & - & + & - & - & - & - & - & - & + & + & - & - & - & - \\
\hline \multicolumn{17}{|l|}{ Production of acid from: } \\
\hline Sorbitol & - & - & + & - & - & $\mathrm{V}$ & - & - & - & - & $\mathrm{V}$ & - & - & - & + & - \\
\hline Trehalose & - & - & - & + & $\mathrm{V}$ & + & + & $\mathrm{V}$ & + & + & + & + & - & + & + & $\mathrm{V}$ \\
\hline Lactose & + & - & + & + & $\mathrm{V}$ & + & $\mathrm{v}$ & + & $\mathrm{v}$ & + & $\mathrm{V}$ & - & - & - & + & + \\
\hline Glycogen & + & + & + & $\mathrm{V}$ & - & - & $\mathrm{v}$ & - & - & ND & - & ND & - & - & - & - \\
\hline Ribose & + & - & - & - & + & + & + & + & - & ND & + & + & + & + & + & - \\
\hline Sucrose & - & + & + & + & + & + & + & + & + & $\mathrm{ND}$ & + & + & - & $\mathrm{ND}$ & + & + \\
\hline Methyl $\beta$-D-glucopyranoside & - & + & + & + & + & - & $\mathrm{V}$ & + & + & $\mathrm{ND}$ & $\mathrm{v}$ & $\mathrm{ND}$ & $\mathrm{ND}$ & ND & + & - \\
\hline
\end{tabular}

${ }^{\star}$ S. canis also differs from $S$. equi subsp. ruminatorum subsp. nov by its inability to produce acid from cyclodextrin and by exhibiting $\alpha$ galactosidase activity.

$\dagger S$. phocae exhibits $N$-acetyl- $\beta$-glucosaminidase activity but not arginine dihydrolase activity. 
reached counts higher than $1 \times 10^{4}$ c.f.u. $\mathrm{ml}^{-1}$, indicating a high excretion rate of this bacterium in milk. These data are indicative of real mammary gland infection and would point to the clinical significance of $S$. equi subsp. ruminatorum subsp. nov. in ruminants as an aetiological agent of mastitis. Except for the well-recognized species of S. uberis, S. agalactiae and S. dysgalactiae, streptococci isolated from mastitis are frequently identified only as Streptococcus spp. (Al-Majali \& Jawabreh, 2003). Therefore, the formal description of $S$. equi subsp. ruminatorum subsp. nov., together with biochemical tests for its identification, will facilitate its identification in clinical veterinary laboratories, thereby allowing a future evaluation of its distribution and clinical prevalence in mastitis in small ruminants.

\section{Description of Streptococcus equi subsp. ruminatorum subsp. nov.}

Streptococcus equi subsp. ruminatorum subsp. nov. (ru.min. a.to'rum. L. n. ruminator -oris ruminant; L. gen. pl. n. ruminatorum of ruminants).

Cells are Gram-positive, non-spore-forming cocci that occur in chains. Colonies are $\beta$-haemolytic, non-pigmented and mucoid after $24 \mathrm{~h}$ on sheep blood agar. Facultatively anaerobic and catalase-negative. Reacts with Lancefield group $\mathrm{C}$ antiserum. Growth does not occur at 10 or $45^{\circ} \mathrm{C}$, at pH 9.6 at $37^{\circ} \mathrm{C}$, or in $6.5 \%(\mathrm{w} / \mathrm{v}) \mathrm{NaCl}$ broth. Bile/aesculin test is negative. In the commercial API Rapid ID 32 Strep system, acid is produced from ribose, cyclodextrin, sorbitol, pullulan, maltose, lactose and glycogen. Acid is not produced from mannitol, trehalose, raffinose, sucrose, tagatose, L-arabinose, D-arabitol, melibiose, melezitose or methyl $\beta$ D-glucopyranoside. Arginine dihydrolase, $\beta$-glucuronidase, alkaline phosphatase and alanine-phenylalanine-proline arylamidase activities are detected. No activity is detected for $\beta$-glucosidase, $\alpha$-galactosidase, $\beta$-galactosidase, pyroglutamic acid arylamidase, $N$-acetyl- $\beta$-glucosaminidase, glycyltryptophan arylamidase or $\beta$-mannosidase. Voges-Proskauer test is negative. Hippurate is hydrolysed but urea and aesculin are not. Positive CAMP test with S. aureus.

The type strain is CECT $5772^{\mathrm{T}}\left(=\right.$ CGUG $47520^{\mathrm{T}}=\mathrm{Mt}$ $167^{\mathrm{T}}$ ). Isolated from milk samples from sheep and goats affected with mastitis.

\section{Acknowledgements}

V. B. was the recipient of a predoctoral grant from the Spanish Ministry of Science and Technology.

\section{References}

Al-Majali, A. M. \& Jawabreh, S. (2003). Period prevalence and etiology of subclinical mastitis in Awassi sheep in southern Jordan. Small Rumin Res 47, 243-248.

Bromage, E. S., Thomas, A. \& Owens, L. (1999). Streptococcus iniae, a bacterial infection in barramundi Lates calcarifer. Dis Aquat Organ 36, $177-181$.
Bruce, J. L. (1996). Automated system rapidly identifies and characterizes microorganisms in food. Food Technol 50, 77-81.

Collins, M. D., Hutson, R. A., Falsen, E., Inganäs, E. \& Bisgaard, M. (2002). Streptococcus gallinaceus sp. nov., from chickens. Int J Syst Evol Bacteriol 52, 1161-1164.

De Ley, J., Cattoir, H. \& Reynaerts, A. (1970). The quantitative measurement of DNA hybridization from renaturation rates. Eur $J$ Biochem 12, 133-142.

Devriese, L. A., Pot, B., Vandamme, P., Kersters, K., Collins, M. D., Alvarez, N., Haesebrouck, F. \& Hommez, J. (1997). Streptococcus hyovaginalis sp. nov. and Streptococcus thoraltensis sp. nov., from the genital tract of sows. Int $J$ Syst Bacteriol 47, 1073-1077.

Devriese, L. A., Vandamme, P., Collins, M. D., Alvarez, N., Pot, B., Hommez, J., Butaye, P. \& Haesebrouck, F. (1999). Streptococcus pluranimalium sp. nov., from cattle and other animals. Int J Syst Bacteriol 49, 1221-1226.

Doit, C., Grimont, F., Whiley, R. A., Régnault, B., Grimont, P. A. D., Hardie, J. M. \& Bouvet, A. (1994). Ribotypes of the "Streptococcus milleri"-group allow discrimination between strains of Streptococcus constellatus, Streptococcus intermedius, and Streptococcus anginosus. In Pathogenic Streptococci, Present and Future, pp. 531-532. Edited by A. Totolian. St Petersburg: Lancer.

Escara, J. F. \& Hutton, J. R. (1980). Thermal stability and renaturation of DNA in dimethyl sulfoxide solutions: acceleration of the renaturation rate. Biopolymers 19, 1315-1327.

Facklam, R. (2002). What happened to the streptococci: overview of taxonomic and nomenclature changes. Clin Microbiol Rev 15, 613-630.

Facklam, R. \& Elliot, J. A. (1995). Identification, classification, and clinical relevance of catalase-negative, gram-positive cocci, excluding the streptococci and enterococci. Clin Microbiol Rev 8, 479-495.

Felsenstein, J. (1989). PHYLIP - phylogeny inference package (version 3.2). Cladistics 5, 164-166.

Fernández-Garayzábal, J. F., Fernández, E., Las Heras, A., Pascual, C., Collins, M. D. \& Domínguez, L. (1998a). Streptococcus parasanguinis: new pathogen associated with asymptomatic mastitis in sheep. Emerg Infect Dis 4, 645-647.

Fernández-Garayzábal, J. F., Collins, M. D., Hutson, R. A., González, I., Fernández, E. \& Domínguez, L. (1998b). Corynebacterium camporealensis sp. nov., associated with subclinical mastitis in sheep. Int J Syst Bacteriol 48, 463-468.

Huß, V. A. R., Festl, H. \& Schleifer, K. H. (1983). Studies on the spectrometric determination of DNA hybridization from renaturation rates. Syst Appl Microbiol 4, 184-192.

Jahnke, K. D. (1992). Basic computer program for evaluation of spectroscopic DNA renaturation data from GILFORD System 2600 spectrometer on PC/XT/AT type personal computer. J Clin Methods $15,61-73$.

Kilian, M. (1998). Streptococcus and Lactobacillus. In Topley \& Wilson's Microbiology and Microbial Infections, pp. 633-667. Edited by A. Balows \& B. I. Duerden. London: Arnold.

Las Heras, A., Domínguez, L. \& Fernández-Garayzábal, J. F. (1999). Prevalence and aetiology of subclinical mastitis in dairy ewes of Madrid region. Small Rumin Res 32, 21-29.

Las Heras, A., Vela, A. I., Fernández, E., Legaz, E., Domínguez, L. \& Fernández-Garayzábal, J. F. (2002). Unusual outbreak of clinical mastitis in dairy sheep caused by Streptococcus equi subsp. zooepidemicus. J Clin Microbiol 40, 1106-1108.

Menzies, P. I. \& Ramanoon, S. Z. (2001). Mastitis of sheep and goats. Vet Clin North Am Food Anim Pract 17, 333-358. 
Pier, G. B. \& Madin, S. H. (1976). Streptococcus iniae sp. nov., a beta hemolytic streptococcus isolated from an Amazon freshwater dolphin, Inia geoffrensis. Int J Syst Bacteriol 26, 545-553.

Quinn, P. J., Carter, M. E., Markey, B. \& Carter, G. R. (1999). The streptococci and related cocci. In Clinical Veterinary Microbiology, pp. 127-136. Edited by P. J. Quinn, M. E. Carter, B. Markey \& G. R. Carter. Edinburgh: Mosby.

Rudney, J. D. \& Larson, C. J. (1994). Use of restriction fragment polymorphism analysis of rRNA genes to assign species to unknown isolates of oral viridans streptococci. J Clin Microbiol 32, 437-443.

Rurangirwa, F. R., Teitzel, C. A., Cui, J., French, D. M., McDonough, P. L. \& Besse, T. (2000). Streptococcus didelphis sp. nov., a streptococcus with marked catalase activity isolated from opossums (Didelphis virginiana) with suppurative dermatitis and liver fibrosis. Int J Syst Evol Microbiol 50, 759-765.

Skaar, I., Gaustad, P., Tønjum, T., Holm, B. \& Stenwig, H. (1994). Streptococcus phocae sp. nov., a new species isolated from clinical specimens from seals. Int J Syst Bacteriol 4, 646-650.
Stefanakis, A., Boscos, C., Alexopoulos, C. \& Samartzi, F. (1995). Frequency of subclinical mastitis and observations on somatic cell counts in ewes' milk in northern Greece. Anim Sci 61, 69-76.

Vela, A. I., Fernández, E., Lawson, P. A., Latre, M. V., Falsen, E., Domínguez, L., Collins, M. D. \& Fernández-Garayzábal, J. F. (2002). Streptococcus entericus sp. nov., isolated from cattle intestine. Int J Syst Evol Microbiol 52, 665-669.

Wayne, L. G., Brenner, D. J., Colwell, R. R. \& 9 other authors (1987). International Committee on Bacterial Systematics. Report of the ad hoc committee on reconciliation of approaches to bacterial systematics. Int J Syst Bacteriol 37, 463-464.

Whiley, R. A., Hall, L. M. C., Hardie, J. M. \& Beighton, D. (1999). A study of small-colony, $\beta$-haemolytic, Lancefield group $\mathrm{C}$ streptococci within the anginosus group: description of Streptococcus constellatus subsp. pharyngis subsp. nov., associated with the human throat and pharyngitis. Int J Syst Bacteriol 49, 1443-1449. 